\title{
AN ANALYSIS THE CHARACTER OF FORREST GUMP MOVIE BY ROBERT ZEMECKIS VIEWED FROM BIG FIVE PERSONALITY TRAITS THEORY
}

\author{
Dwi Sakti Manggalasari; Dian Luthfiyati \\ dwimanggasari@gmail.com; dian.luthfiyati@gmail.com \\ Pendidikan Bahasa Inggris, FKIP, Universitas Islam Lamongan
}

\begin{abstract}
The purpose of this research is to know the character and characterization of Forrest Gump as main character in the movie by analyzing the evidence from the dialogues and his actions in the movie. To know what the character and characterization of Forrest, the writer used the method descriptive-qualitative. The writer employs himself to collect the data by reading script, watching the movie and classifying them. The writer focused the dialogues of the movie, and then followed by classifying and analyzing the character and characterization through the big five personality theory The writer found that The Character in the movie are Forrest as Protagonist Character and Forrest as mayor Character. The Forrest character in the movie viewed the Big Five personality, Forrest have all the type of the character such as Openness, Contentiousness, Extraversion or Introversion, Agreeableness, and Neuroticism, but the dominate of Forrest character is Agreeableness. Forrest have high agreeableness, he have the character flexible, trusting, cooperative, forgiving, empathic, soft-hearted, tolerant.
\end{abstract}

Keywords: Character, big five personality

\section{INTRODUCTION}

Several literary works have been made in many forms. One of them is a film. Film encompasses individual motion pictures, the field of film as an art form, and the motion picture industry.

The most obvious difference between film and movie is the fact that a film is recorded and preserved rather than individually staged in the unique and unrepeatable manner of a theater performance. Films, and particularly video tapes, are like novels, which in theory can be repeatedly read, or viewed. Every theatrical performance involving a particular director, specific actors, and scenery is a unique event that eludes exact repetition. A film, on the other hand, can be shown in different cities at the same time, and it would be impossible to judge one screening as better or worse than any other one since the film always remains the same in its thousands of identical copies. In sum, one can say that although performance is at the heart of both drama and film, it takes on a completely different character in film, due to the idiosyncrasies of a mechanically reproducible medium. Klaler: 2005).

A film could not be form without a story in it. It also happen in story, story could not be called as a story without any characters in it. In literary works character and characterization are important elements because they build the story.

In this research the researcher interest to analyze the movie entitle Forrest Gump, "the character of Forrest Gump in movie" because Forrest have many character that played in movie, it is interesting to know what are the characters that have by Forrest.

So the researcher choose the title "An Analysis the Main character of Forrest Gump Movie viewed big five personality traits theory"

According to Phelan, character is a literary element composed of three components: the mimetic, synthetic and thematic. The mimetic component refers to how a character can be the image of a real and possible person. The synthetic component concerns the artificiality of character, that is to say it stresses that 
character is a literary construct. (Weststeijn: 2004).

An individual's character is that person's collection of character traits and these can be defined as relatively stable dispositions to think, feel, and behave in certain ways in certain situations. (Webber: 2006).

Characterization is the process by which the writer reveals the personality of a character. Characterization is revealed through direct characterization and indirect characterization.

Characterization is classified according to the dimensions in which it revolves. Most of the plays are classified under four main dimensions such as physical, social, psychological and spiritual dimension. The characterization concentrated with physical dimension exists mainly with the ideas based on human and physical capabilities. Such types of drama are mainly governed by set of conventions and make an impact over the audience concentrating the emotion or amusement. (IOSR Journal of Humanities And Social Science (IOSR-JHSS)

In fictional literature, authors use many different types of characters to tell their stories. There are types of character such as Mayor and Minor, Dynamic and static, Round and Flat, Protagonist and antagonist. (Karen Bernardo, Characterization in Literature)

\section{The Big Five Personality Theory}

The Five Factor Model of personality, also known as the "Big Five", is perhaps one of the most frequently discussed personality taxonomies of recent times (Goldberg: 1990). The five personality factors that constitute this model are: 1) Extraversion - sociability, dominance, ambition, positive emotionality and excitement-seeking; 2) Agreeableness - cooperation, trustfulness, compliance, and affability; 3) Emotional Stability - lack of anxiety, hostility, depression, and personal insecurity; 4) Conscientiousness - dependability, achievement striving, and plan fullness; and 5) Openness to Experienceintellectance, creativity, unconventionality, and broadmindedness (Barrick, and Mount: 2001). Ii is also said by Lizzette (2004).

Lewis Goldberg proposed a five personality model, nickname the Big Five:

- Openness to experience: the tendency to be imaginative, independent, and interest in variety vs. Practical, conforming, and interested in routine.

- Conscientiousness: the tendency to be organizing, careful, and discipline vs. Disorganized, careless, and impulsive.

- Extraversion: the tendency to be sociable, fun-loving, and affectionate vs. Retiring, somber and reserved.

- Agreeableness: the tendency to be softhearted, trusting, and helpful vs. Ruthless, suspicious, and uncooperative.

- Neuroticism: the tendency to be calm, secure, and self-satisfied vs. Anxious, insecure, and self-pitying.

\section{METHOD}

In this research is use qualitative research. Qualitative research is multi method in focus, involving an interpretive, naturalistic approach to its subject matter. This means that qualitative research study things in their natural settings, attempting to make sense of, one interpreted phenomena in terms of the meanings people bring to them. Qualitative research involves the study, personal experience, introspective, life story, interview, observational, historical, interactional and visual text-that describe routine and problematic moments and meanings in individual's lives. (Wahyuni: 2015).

The research used two kinds of the data such as the primary data and the secondary data. The primary data is the movie and the script of the movie Forrest Gump. And the secondary data are some books that related with the research, some journal and eBook from the internet. 
In this qualitative research the writer used:

1. Documentation.

2. The writer download the movie

3. Watch the movie repeatly and read the transcript to help more understand with the movie.

According to Bogdan and Biklen in Meloeng book's, define qualitative analysis as "working with data, organizing data, breaking it into manageable units, synthesizing it, searching for patterns, discovering what is important and what is to be learned, and deciding what you will tell others.

Data analysis in this study uses some steps, such us:

a. Classifying, the writer classified the data that are similar.

b. Analyzing, the writer analyze every data that found from the movie or script.

\section{DISCUSSION AND FINDING}

The Forrest Character in the movie is Forrest as Protagonist Character and Forrest as mayor Character.

The main character has very important role in the development of the story, because the main character presents conflicts and significant actions that build the film. This main character is Forrest Gump, played by Tom Hanks. The movie tells about his life from beginning until the end of the movie.

Forrest as Mayor character because this movie itself tells about his life since he stupid person become a Successes person with his carefulness. Forrest has big role in the development of the story, because he is main character that dominates the character in the story.

According to the big five personality theory, Forrest has all the characters; these are Openness, Contentiousness,

Extraversion/Introversion, Agreeableness, and Neuroticism.
Forrest have character to Openness with another people, he ask another people to talking with him and tell anything about him, although he didn't know who the woman is. Openness is the characteristic more active, want to know, creative, and imaginative (Pervin, A.L, Daniel C. Oliver P.J. 2010. Psikologi Kepribadian teori dan penelitian. Kharisma Putra Utama)

Forrest is person energy in directed inward. He doesn't say anything and just gasping and panting. Introversion means that the person's energy is directed inward. This could include being rigid, reliable, sober or controlled. In all these traits, energy is directed inward. (Ellen P. and Doyle P.S,. 2009What is Psychology?. USA)

Forrest can be socialization, active, like conversation. Extraversion is the asses the quantity and interpersonal interaction intensity, level activity and the enjoy capacity. The characteristic of Extraversion are can be socialization, active, like conversation, optimism, and happiness. (Costa \& McCreae: 1992)

Forrest has agreeableness, because agreeableness is assessing the quality interpersonal from what they think, they feel, and they do. The characteristic of agreeableness are friendly, can be trust, want to helping another people, can be forgiven, and easy to personal persuade. (Pervin, A.L, Daniel C. Oliver P.J: 2010)

Forrest feel disappointed because Jenny was gone without say good bye wit Forrest. The character is neuroticism, because is the negative feeling, include anxiousness, sadness, brittleness, and stress.

\section{CONCLUSION}

The Five Factor Model of personality, also known as the "Big Five", is perhaps one of the most frequently discussed personality taxonomies of recent times (Goldberg, 1990).

The five personality factors that constitute this model are: 1) Extraversion - 
sociability, dominance, ambition, positive emotionality and excitement-seeking; 2) Agreeableness - cooperation, trustfulness, compliance, and affability; 3) Emotional Stability - lack of anxiety, hostility, depression, and personal insecurity; 4) Conscientiousness - dependability, achievement striving, and planfullness; and 5) Openness to Experience intellectance, creativity, unconventionality, and broadmindedness.

Lizzette L. 2004. Personality and motivational characteristics of the successful mentor. University of South Florida.

The Forrest character according to the big five personality theory, Forrest have all the character, that are Openness, Contentiousness,

Extraversion/Introversion, Agreeableness, and Neuroticism.

\section{REFERENCES}

Ellen P. and Doyle P.S,. 2009What is Psychology?. USA)

Klaler, M. 2005. An Introduction to Literature Second Edition. USA and Canada: Routledge

Lizzette L,. 2004. Personality and motivational characteristics of the successful mentor. University of South Florida.

Moloeng Lexy J, 2006. Metodologi

Penelitian Kualitatif. PT Remaja Rosdakarya Offset. Bandung

Pervin, A.L, Daniel C. Oliver P.J. 2010. Psikologi Kepribadian teori dan penelitian. Kharisma Putra Utama

Vidhya.B, Dr.A.Arjunan IOSR Journal of Humanities And Social Science (IOSR-JHSS

Wahyuni.S., 2015. Qulitative Research Method theory and Practice. Jakarta : Salemba Empat
Weststeijn. W.G., 2004. Towards a Cognitive Theory of Character. Hamburg University Press

https://books.google.filmgenreforscreenwr iter/ 